\title{
Comparison of Outcomes between 7-French and 10-French Plastic Stents for Patients with Biliary Tract Cancer
}

\author{
Kyong Joo Lee*, Yong Seok Kang*, Jae Ho Seong, Saehyun Jung, Jae Woo Kim \\ Department of Internal Medicine, Yonsei University Wonju College of Medicine, Wonju, Korea
}

Background/Aim: There is little data on whether plastic stents with a larger diameter are patent for longer than small stents in patients with bile duct cancer. The aim of this study was to compare the stent survival between 7-French (Fr) and 10-Fr plastic stents and evaluate the factors affecting stent survival.

Methods: Patients with biliary obstruction due to biliary tract cancer were enrolled at Yonsei University Wonju College of Medicine from January 2010 to October 2014.

Results: A total of 215 patients (7-Fr:10-Fr $=89: 126$ patients) were retrospectively enrolled. The primary tumor sites were common bile duct $(n=111)$, hilar $(n=45)$, and ampulla of Vater $(n=59)$. Rates of stent migration and stent obstruction were not different between the two groups. The median duration of stent survival was 3.3 months in the 7-Fr group and 5.9 months in the 10-Fr group ( $p=0.543)$. The diameter of the stent did not have an effect on stent survival (hazard ratio 1.11, $95 \%$ confidence interval 0.71-1.73, $p=0.649$ ).

Conclusions: $7-\mathrm{Fr}$ and 10-Fr stents have similar rates of stent migration and stent obstruction. The stent survival of 7-Fr was not inferior to $10-\mathrm{Fr}$ stents in the management of biliary tract cancer.

Korean J Pancreas Biliary Tract 2017;22(4):165-171

Keywords: Biliary tract cancer, Stents, Survival

\begin{abstract}
Received Apr. 5, 2017
Revised May. 9, 2017

Accepted May. 9, 2017
\end{abstract}

Corresponding author : Jae Woo Kim

Department of Internal Medicine, Yonsei University

Wonju College of Medicine, 20 IIsan-ro, Wonju 26426, Korea

Tel. +82-33-741-0501 Fax. +82-33-741-0951

E-mail; jawkim96@yonsei.ac.kr

* Kyong Joo Lee and Yong Seok Kang contributed equally to this work as first author

This is an Open Access article distributed under the terms of the Creative Commons Attribution Non-Commercial License (http:// creativecommons.org/licenses/by-nc/3.0/) which permits unrestricted non-commercial use, distribution, and reproduction in any medium, provided the original work is properly cited.

Copyright $\odot 2017$ by The Korean Journal of Pancreas and Biliary Tract

\section{INTRODUCTION}

Endoscopic biliary drainage by stenting has become a standard management for obstructive jaundice caused by malignancy. ${ }^{1-4}$ Endoscopic stent insertion for an obstructed biliary tract was first performed by Soehendra and Reynders-Frederix in $1980^{3}$ and since then, has become a widely established method to relieve cholangitis and pain and reduce mortality and morbidity from malignant biliary obstruction. ${ }^{5}$ However, the limitations of biliary stenting are stent occlusion and migration. Many patients are required to undergo endoscopic retrograde cholangiopancreatography (ERCP) again or other interventions such as percutaneous transhepatic biliary drainage (PTBD). There are two types of biliary stents, plastic stent 
(PS) and metal stent (MS). Although many studies have shown a longer survival and less need for re-intervention with MS compared to PS, PS is usually first tried in biliary tract cancer. ${ }^{6}$ PSs are easier to remove and cheaper compared to MS. Moreover, it is a difficult decision as to when to insert MS because the biliary stricture may not be confirmed or staging work-up is not finished. PSs can be easily removed by forceps and a biopsy or brush cytology can be retried to obtain tissue samples from lesions.

There are various diameters of plastic stents, ranging from 5-French (FR) to 12-Fr. ${ }^{7} \mathrm{~A}$ few studies report that small stents provide better survival, while most studies report that larger stents are better. ${ }^{8,9}$ The outer diameter of plastic stents is limited by the internal diameter of the instrument channel of the endoscope. A large-diameter stent makes an endoscope less flexible and more difficult to use. When removing PS, larger stent (10-Fr) usually need to be pulled out by the endoscope because it is difficult to remove via the channel of the endoscope, while smaller stent (7-Fr) can be removed easily through the instrument channel of an endoscope. There are a few studies comparing the efficacy and complications between 7-Fr PS and 10-Fr PS. In this study, we compared the technical and clinical success rate, stent survival, and complications of 7-Fr and 10-Fr stents in first diagnosed biliary tract cancer. In addition, we tried to identify factors affecting stent survival.

\section{METHODS}

\section{Patients}

Patients who were first diagnosed with biliary obstruction due to biliary tract cancer were retrospectively reviewed at Yonsei University Wonju College of Medicine from January 2010 to October 2014. Inclusion criteria were patients with pathologically proven hilar cancer, common bile duct (CBD) cancer, and ampulla of Vater cancer. All operable and inoperable cases were included. Exclusion criteria were patients who were inserted MS at initial treatment and who were not histologically proved as biliary tract cancer. The study was approved by the Institutional Review Board for Human Research. The need for informed consent was waived because the data were anonymized before analysis.

\section{Procedural technique}

Two endoscopists (K.J.L and J.W.K) performed ERCP. An endoscope (TJF-240V or TJF-260V; Olympus, Tokyo, Japan) with a working channel of $4.2 \mathrm{~mm}$ diameter was used. A 0.035-inch guidewire (Jagwire; Boston Scientific, Natick, MA, USA) was introduced through the malignant obstruction. Endoscopic sphincterotomy was always done before insertion of the PS. Only one straight 7-Fr or 10-Fr PS (Percuflex; Boston Scientific, Marlborough, MA, USA) was advanced through the obstructed biliary tract and then placed under fluoroscopic guidance.

\section{Outcomes measure and follow-up schedule}

The 7-Fr and 10-Fr stent groups were compared for the technical success rate of stent deployment, clinical success rate, number of stent occlusions or migrations, and stent survival. Technical success was defined as successful stent insertion with bile drainage from the PS. Clinical success was defined as a statistically significant decrease in the total bilirubin level after 3 days of stent deployment. Laboratory parameters such as white blood count, C-reactive protein, aspartate aminotransferase (AST), alanine aminotransferase (ALT), alkaline phosphatase, gamma-glutamyl transferase, and total bilirubin were measured prior to endoscopic stent placement. Samples were obtained before and 3 days after stent placement. All complications, such as migration and obstruction, were evaluated in each group. Stent migration was defined as proximal migration of the distal flap into the lumen of the CBD or distal migration of the stent into the duodenal lumen by radiological imaging. Stent obstruction was defined as the development of cholangitis or worsening jaundice. Stent survival was the time interval between stent insertion and replacement or removal.

\section{Statistical analysis}

All statistical analyses were performed with PASW statistical software (version 18.0; SPSS Inc., Chicago, IL, USA). The paired $t$-test was used to compare continuous measures, and 
the chi-square test was used to compare categorical measures. Changes in laboratory levels before and after stent insertion were compared within the same group using a paired $t$-test. To assess differences in laboratory levels between the two groups at baseline and after stent insertion, we performed a linear mixed model for repeated measurements. Two effects were included: one within-group time effect (before and after stent insertion) and one between-group stent diameter effect. Cox regression analysis was used to identify the factors affecting stent survival. A significant difference was noted when the $p$ value was $<0.05$.

\section{RESULTS}

\section{Patient characteristics}

A total of 215 patients with biliary tract cancer underwent ERCP for decompression of the bile duct (Table 1). Eightynine patients received 7-Fr PS and 126 patients received 10-Fr PS. There were 126 men and 89 women. The primary tumor sites were the CBD $(n=111)$, hilar $(n=45)$, and ampulla of Vater $(\mathrm{n}=59)$. The mean length of the stents in the 7-Fr group was not different with the 10-Fr group.

\section{Clinical outcomes and stent survival}

The technical success rates of stent insertion were $100 \%$ in both groups (Table 2). The number of patients who need to change stents during follow up was not different between the two groups. The median stent survival between the 7-Fr group and 10-Fr group was not statistically different (3.3 months vs. 5.9 months, $p=0.543$, Fig. 1). The cumulative stent survival rates for 7-Fr PS at 6 and 12 months were $48 \%$ and $42 \%$, respectively. The cumulative stent survival rate for 10 -Fr PS at 6 and 12 months were $51 \%$ and $42 \%$, respectively. The levels of AST, ALT, and total bilirubin decreased significantly after stent insertion in both groups. According to linear mixed-model analysis, the changes in AST, ALT, and total bilirubin between groups were not significant (Table 3). We tried to identify factors affecting stent survival by using Cox regression analysis (Table 4). The hazard ratio of 7-Fr PS was 1.11 (95\% confidence interval [CI], 0.71-1.73) but it was not significant $(p=0.649)$.

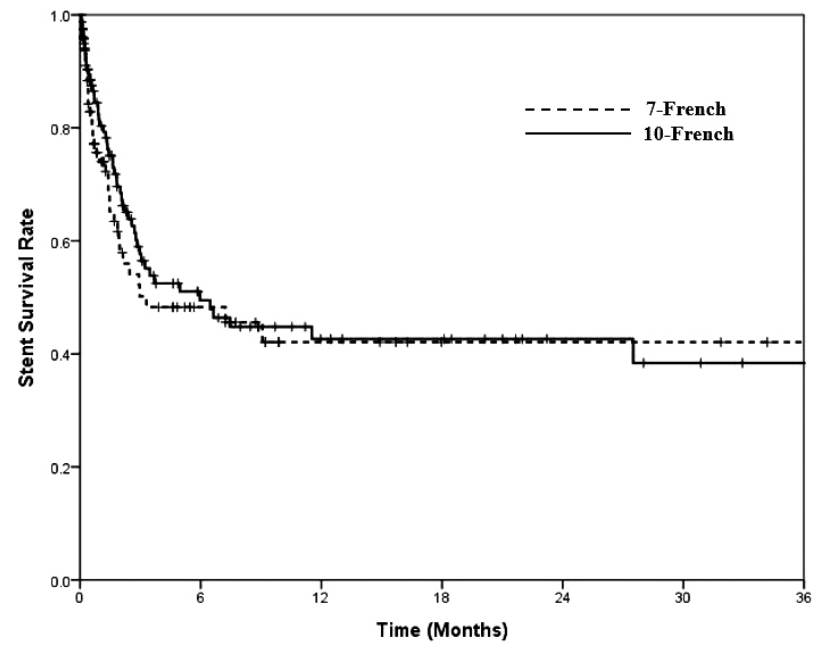

Fig. 1. Stent survival of 7-French (Fr) and 10-Fr plastic stents.

Table 1. Patient characteristics

\begin{tabular}{|c|c|c|c|}
\hline & $7-\operatorname{Fr}(n=89)$ & $10-\operatorname{Fr}(n=126)$ & $p$-value \\
\hline Sex (male:female) & 54 (60.7):35 (39.3) & $72(57.1): 54(42.9)$ & 0.605 \\
\hline Age (years) & $71.5 \pm 10.5$ & $71.7 \pm 10.2$ & 0.856 \\
\hline Primary tumor site & & & 0.210 \\
\hline Common bile duct & $46(51.7)$ & 65 (51.6) & \\
\hline Hilar & $23(25.8)$ & $22(17.5)$ & \\
\hline Ampulla of Vater & $20(22.5)$ & $39(31)$ & \\
\hline Presence of metastasis & $32(36)$ & $37(29.4)$ & 0.308 \\
\hline Length of stent (cm) & $10.9 \pm 1.7$ & $10.6 \pm 1.8$ & 0.274 \\
\hline
\end{tabular}

Values are presented as mean \pm standard deviation or number (\%). Nominal variables were analyzed by chi-square and continuous variables were analyzed by paired $t$-test.

Fr, French. 
Table 2. Clinical outcomes

\begin{tabular}{|c|c|c|c|}
\hline & $7-\operatorname{Fr}(n=89)$ & $10-\operatorname{Fr}(n=126)$ & $p$-value \\
\hline Technical success & $100 \%(89 / 89)$ & $100 \%(126 / 126)$ & - \\
\hline Reintervention & $42(47.7 \%)$ & $51(41.1 \%)$ & 0.340 \\
\hline Migration & 11 & 18 & \\
\hline Stent obstruction & 31 & 33 & \\
\hline Stent survival, median & 3.3 months (range, 0-9.6) & 5.9 months (range, 1.6-10.3) & 0.543 \\
\hline
\end{tabular}

Fr, French.

Table 3. Laboratory findings before and after plastic stent insertion

\begin{tabular}{|c|c|c|c|}
\hline & $7-\operatorname{Fr}(n=89)$ & $10-\operatorname{Fr}(n=126)$ & $p$-value* \\
\hline White blood count & & & 0.375 \\
\hline Before $\left(/ \mathrm{mm}^{3}\right)$ & $9,178 \pm 4,187$ & $9,263 \pm 5,525$ & \\
\hline After $\left(/ \mathrm{mm}^{3}\right)$ & $8,285 \pm 3,474$ & $8,226 \pm 4,125^{\dagger}$ & \\
\hline Aspartate aminotransferase & & & 0.154 \\
\hline Before $(U / L)$ & $132.9 \pm 106.1$ & $162.7 \pm 184.3$ & \\
\hline After (U/L) & $70.8 \pm 98.7^{\dagger}$ & $74.9 \pm 78.4^{\dagger}$ & \\
\hline Alanine aminotransferase & & & 0.404 \\
\hline Before (U/L) & $140.1 \pm 137.2$ & $168.1 \pm 170.8$ & \\
\hline After (U/L) & $76.1 \pm 76.1^{\dagger}$ & $94.1 \pm 113.7^{\dagger}$ & \\
\hline Total bilirubin & & & 0.138 \\
\hline Before (mg/dL) & $7.1 \pm 6.8$ & $7.7 \pm 7.3$ & \\
\hline After (mg/dL) & $4.2 \pm 5.2^{\dagger}$ & $4.6 \pm 5.0^{\dagger}$ & \\
\hline C-reactive protein & & & 0.757 \\
\hline Before (mg/dL) & $6.5 \pm 7.2$ & $5.5 \pm 6.6$ & \\
\hline After (mg/dL) & $5.1 \pm 5.4$ & $4.5 \pm 5.3^{\dagger}$ & \\
\hline
\end{tabular}

Values are presented as mean \pm standard deviation.

Fr, French.

${ }^{*} p$ values were calculated as interactions of stent diameter and time by linear mixed model.

${ }^{\dagger} p<0.05$, compared with baseline by paired $t$-test.

Table 4. Cox regression analysis of the stent diameter on stent survival

\begin{tabular}{llll}
\hline & HR & $\mathbf{9 5 \%}$ Cl & $p$-value \\
\hline Sex (male) & 1.21 & $0.77-1.90$ & 0.402 \\
Age & 1.01 & $0.99-1.03$ & 0.265 \\
Primary tumor site & & & 0.833 \\
Common bile duct & 1 & & $0.58-1.53$ \\
Hilar & 0.95 & $0.28-1.04$ & 0.069 \\
Ampulla of Vater & 0.55 & $0.40-1.05$ & 0.080 \\
Presence of metastasis & 0.65 & $0.94-1.19$ & 0.340 \\
Length of stent & 1.05 & $0.71-1.73$ & 0.649 \\
Stent diameter (7-Fr) & 1.11 & & \\
\hline
\end{tabular}

$\mathrm{HR}$, hazard ratio; $\mathrm{Cl}$, confidence interval; Fr, French. 


\section{DISCUSSION}

Endoscopic biliary drainage is the preferred management option for patients with biliary tract cancer and has been reported to improve quality of life. Endoscopic stenting is as effective as surgery for palliation in patients with inoperable cancer. ${ }^{10}$ Endoscopic stenting has a lower early mortality and fewer complications than surgical management, but these patients require follow-up ERCP to exchange the stent when necessary for obstruction or migration. ${ }^{1,11,12}$

Stent obstruction is a clinically significant problem and many attempts have been made to improve stent survival. Most causes of stent failure and obstruction are tumor overgrowth, ingrowth, and bile sludge. Since deposition of sludge in biliary stents is not preventable, effective attempts to prolong stent survival currently require the use of large-diameter stents. In the opinion of many expert endoscopists, with the availability of ERCP for larger-sized stents, there is a tendency towards placing stents of 10-Fr or larger because they believe that the larger-sized stents are more effective for jaundice and have a lower incidence of obstruction. Several reports have attested 10-Fr or larger stents are more effective for biliary drainage. ${ }^{9,13,14}$ Rey et al. ${ }^{15}$ reported that increasing the stent internal diameter by $0.2 \mathrm{~mm}$ increased the bile flow by $300 \%$. Siegel et al. ${ }^{14}$ showed that the duration of survival of 12-Fr PS was longer than that of 10-Fr PS (190 vs 150 days) and recommended routine use of larger stents. On the other hand, some retrospective studies failed to show that larger stents have any significant effect in palliative management or duration of stent survival. ${ }^{8,16,17}$

The question whether a larger diameter is significantly better for a PS has clinical importance because the PS has been often used for the palliation of patients with malignant biliary obstruction. ${ }^{18,19}$ In our study, we compared the stent survival of 7-Fr and 10-Fr PS for management of patients with biliary tract cancer. The number of reinterventions and stent survival were not different between the two groups. F.M. Pedersen also reported no definitive difference in median stent survival between 7-Fr and 10-Fr PS in malignant biliary obstruction. ${ }^{20}$ However, a $13.9 \%$ complication rate for 7-Fr PS occurred as compared with a $16.7 \%$ complication rate for 10-Fr PS. ${ }^{20}$ The levels of AST, ALT, and total bilirubin were effectively decreased after stent insertion regardless of stent diameter. Moreover, the differences were not statistically significant on linear mixed-models. In addition, the stent diameter was not related to stent survival by Cox regression analysis. Matsuda et al. ${ }^{16}$ reported that factors such as diameter and length of the PS were not significantly related to duration of survival. Sasahira et al. ${ }^{21}$ also failed to show PS with a larger diameter prolonged stent survival.

In our study, the success rate of stent insertion was 100\% for both 7-Fr and 10-Fr stents. The 10-Fr stents were more difficult to insert and handle because of the stricture of biliary duct although the time to stent insertion was not measured. Smaller-caliber stents such as 7-Fr PS have an advantage when entering tight strictures that are difficult to traverse, ${ }^{7} 7$-Fr PS might have advantage for hilar cancer. Also, 7-Fr PSs are more flexible and easier to remove compared to 10-Fr PSs. When removing 7-Fr PSs, it is possible to easily remove them by grasping them with the forceps through the instrumental channel of the endoscope. However, when removing a 10-Fr PS, the endoscope often has to be pulled out after catching the PS by the snare and it is hard to extract with forceps. Considering the stent survival and the number of changes were not different between 7-Fr PS and 10-Fr PS, 7-Fr PS should be preferred as the first plastic stent in bile duct cancer.

There are some limitations to this study. First, the study is retrospective and not randomized. Although the success rate was $100 \%$ in both groups in this study, the endoscopists might have selected 7-Fr PS rather than 10-Fr PS in difficult cases because a smaller diameter PS is more flexible and easier to insert into an obstructed bile duct than a larger diameter PS. Therefore, bias could have occurred. Second, the tumor sites were heterogeneous and the length of the stent differed according to the tumor site. Third, the procedure time was not evaluated to compare the feasibility of stent insertion. However, quite a large number of cases were analyzed and multivariate analysis was performed to consider confounding factors.

In conclusion, our study demonstrated that 7-Fr stents have similar stent migration or stent obstruction rate to $10-\mathrm{Fr}$ 
stents, and their stent survival was not inferior to 10-Fr stents in the management of malignant biliary obstruction. Further prospective and large studies are required to confirm the results of our study.

\section{요 약}

배경/목적: 담도암에서 플라스틱 스텐트 너비에 따른 스텐 트 생존 차이에 대한 데이터는 부족하다. 이번 연구의 목적은 담도암에서 7-프렌치와 10-프렌치 플라스틱 스텐트의 생존 차 이를 보고 어떤 인자가 개방성에 영향을 미치는지 확인하고자 한다.

방법: 2010년 1월부터 2014년 10월까지 연세대학교 원주세 브란스기독병원에서 담도암으로 담도가 막힌 환자들을 등록 하였다.

결과: 총 215 명(7-프렌치:10-프렌치 = 89명:126명)의 환자 를 후향적으로 등록하였다. 암의 위치는 총담관(111명), 간문 부 담관(45명), 바터팽대부(59명)였다. 스텐트 이동이나 폐쇄 는 두 군 간에 통계적 차이가 없었다. 중앙 스텐트 생존은 7-프 렌치의 경우 3.3 개월이었고 10 -프렌치의 경우 5.9 개월이었다 $(p=0.543)$. 플라스틱 스텐트 너비는 스텐트 생존에 영향을 미 치지 않았다(Hazard Ratio: 1.11, 95\% CI 0.71-1.73, $p=0.649$ ).

결론: 담도암 치료에 있어 7-프렌치와 10-프렌치 플라스틱 스텐트는 스텐트 이동이나 폐쇄 차이가 없었고 스텐트 생존에 있어 7-프렌치 플라스틱 스텐트가 10-프렌치에 비해 열등하지 않았다.

국문 색인: 담도암, 스텐트, 생존

\section{Conflicts of Interest}

The author has no conflicts to disclose.

\section{Acknowledgment}

This work was supported by the National Research Foundation of Korea (NRF) grant funded by the Korea government (MSIP) (No. NRF-2016R1C1B1007909).

\section{REFERENCES}

1. Andersen JR, Sørensen SM, Kruse A, Rokkjaer M, Matzen P. Randomised trial of endoscopic endoprosthesis versus operative bypass in malignant obstructive jaundice. Gut 1989;30:1132-1135.

2. Lee KJ, Chung MJ, Park JY, et al. Clinical advantages of a metal stent with an S-shaped anti-reflux valve in malignant biliary obstruction. Dig Endosc 2013;25:308-312.

3. Soehendra N, Reynders-Frederix V. Palliative bile duct drainage - a new endoscopic method of introducing a transpapillary drain. Endoscopy 1980;12:8-11

4. Wagh MS, de Bellis $M$, Fogel EL, et al. Multicenter randomized trial of 10-French versus 11.5-French plastic stents for malignant biliary obstruction. Diagn Ther Endosc 2013;2013:891915.

5. Abraham NS, Barkun JS, Barkun AN. Palliation of malignant biliary obstruction: a prospective trial examining impact on quality of life. Gastrointest Endosc 2002;56:835-841.

6. Kawashima H, Itoh A, Ohno E, Goto H, Hirooka Y. Should plastic stents be avoided in all unresectable malignant perihilar biliary strictures? Dig Endosc 2013;25 Suppl 2:86-89.

7. Somogyi L, Chuttani R, Croffie J, et al. Biliary and pancreatic stents. Gastrointest Endosc 2006;63:910-919.

8. Kadakia SC, Starnes E. Comparison of 10 French gauge stent with 11.5 French gauge stent in patients with biliary tract diseases. Gastrointest Endosc 1992;38:454-459.

9. Huibregtse K, Tytgat GN. Palliative treatment of obstructive jaundice by transpapillary introduction of large bore bile duct endoprosthesis. Gut 1982;23:371-375.

10. Taylor MC, McLeod RS, Langer B. Biliary stenting versus bypass surgery for the palliation of malignant distal bile duct obstruction: a metaanalysis. Liver Transpl 2000;6:302-308.

11. Raikar GV, Melin MM, Ress A, et al. Cost-effective analysis of surgical palliation versus endoscopic stenting in the management of unresectable pancreatic cancer. Ann Surg Oncol 1996;3:470-475.

12. Smith AC, Dowsett JF, Russell RC, Hatfield AR, Cotton PB. Randomised trial of endoscopic stenting versus surgical bypass in malignant low bileduct obstruction. Lancet 1994;344:1655-1660.

13. Siegel JH. Improved biliary decompression with large caliber endoscopic prostheses. Gastrointest Endosc 1984;30:21-23.

14. Siegel JH, Pullano W, Kodsi B, Cooperman A, Ramsey W. Optimal palliation of malignant bile duct obstruction: experience with endoscopic 12 French prostheses. Endoscopy 1988;20:137-141.

15. Rey JF, Maupetit P, Greff M. Experimental study of biliary endoprosthesis efficiency. Endoscopy 1985;17:145-148.

16. Matsuda Y, Shimakura K, Akamatsu T. Factors affecting the patency of stents in malignant biliary obstructive disease: univariate and multivariate analysis. Am J Gastroenterol 1991;86:843-849.

17. Frakes JT, Johanson JF, Stake JJ. Optimal timing for stent replacement in 
malignant biliary tract obstruction. Gastrointest Endosc 1993;39:164167.

18. Davids PH, Groen AK, Rauws EA, Tytgat GN, Huibregtse K. Randomised trial of self-expanding metal stents versus polyethylene stents for distal malignant biliary obstruction. Lancet 1992;340:1488-1492.

19. Schmassmann A, von Gunten E, Knuchel J, Scheurer U, Fehr HF, Halter F. Wallstents versus plastic stents in malignant biliary obstruction: effects of stent patency of the first and second stent on patient compliance and survival. Am J Gastroenterol 1996;91:654-659.

20. Pedersen FM. Endoscopic management of malignant biliary obstruction. Is stent size of 10 French gauge better than 7 French gauge? Scand J Gastroenterol 1993;28:185-189.

21. Sasahira N, Hamada T, Togawa O, et al. Multicenter study of endoscopic preoperative biliary drainage for malignant distal biliary obstruction. World J Gastroenterol 2016;22:3793-3802. 